\title{
A Study on Transformation of Higher Education System: Present Scenario and Future Outlook
}

\author{
Hegde Lata Narayan ${ }^{1}$ \& Shailashri V.T. ${ }^{2}$ \\ ${ }^{1}$ Research Scholar, College of Management \& Commerce, Srinivas University, Mangalore, \\ India.OrcidID:0000-0003-3326-3715, E-mail: lathah69@ gmail.com \\ ${ }^{2}$ Research Professor, College of Management and Commerce, Srinivas University, \\ Mangalore, India.OrcidID:0000-0002-1684-238X, E-mail: shailashrivt@gmail.com
}

Area/Section: Business Management.

Type of the Paper: Conceptual analysis.

Type of Review: Peer Reviewed as per $|\mathrm{C}| \mathrm{O}|\mathrm{P}| \mathrm{E} \mid$ guidance.

Indexed in: OpenAIRE.

DOI: https://doi.org/10.5281/zenodo.5145600

Google Scholar Citation: IJMTS

\section{How to Cite this Paper:}

Lata Narayan, Hegde, \& Shailashri, V. T., (2021). A Study on Transformation of Higher Education System: Present Scenario and Future Outlook. International Journal of Management, Technology, and Social Sciences (IJMTS), 6(1), 1-11. DOI: https://doi.org/10.5281/zenodo.5145600.

International Journal of Management, Technology, and Social Sciences (IJMTS) A Refereed International Journal of Srinivas University, India.

CrossRef DOI: https://doi.org/10.47992/IJMTS.2581.6012.0149

(C) With Author.

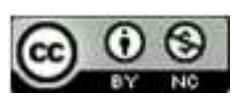

This work is licensed under a Creative Commons Attribution-Non-Commercial 4.0 International License subject to proper citation to the publication source of the work.

Disclaimer: The scholarly papers as reviewed and published by the Srinivas Publications (S.P.), India are the views and opinions of their respective authors and are not the views or opinions of the SP. The SP disclaims of any harm or loss caused due to the published content to any party. 


\title{
A Study on Transformation of Higher Education System: Present Scenario and Future Outlook
}

\author{
Hegde Lata Narayan ${ }^{1} \&$ Shailashri V.T. ${ }^{2}$ \\ ${ }^{1}$ Research Scholar, College of Management \& Commerce, Srinivas University, Mangalore, \\ India. OrcidID: 0000-0003-3326-3715, E-mail: lathah69@ gmail.com \\ ${ }^{2}$ Research Professor, College of Management and Commerce, Srinivas University, \\ Mangalore, India. OrcidID: 0000-0002-1684-238X, E-mail: shailashrivt@ gmail.com
}

\begin{abstract}
Purpose: An analysis of Higher education in India gives insight into its present system, the transformation it has undergone and its future outlook. In this paper, we have made an honest attempt to understand the system, constitution, transformation, opportunities and challenges, and to offer necessary suggestions.

Design/Methodology/Approach: It is a qualitative conceptual study, based on secondary data. Secondary data is collected from websites, research papers, journals, articles, various surveys \& Government reports. This study includes discussion with experts from the field of Higher education.
\end{abstract}

Findings/Result: Based on detail analysis of the constitution, transformation, NEP 2020 for a futuristic outlook in Indian Higher Education, SWOT analysis and challenges. There is a crucial need to relook at the financial funds, access and equity. To boost higher education in India, it is necessary to adopt strategic approach for tackling the various challenges.

Originality/Value: This paper analyses and interprets the transformation of Indian Higher Education system with reference to its constitutions, SWOT analysis and challenges. Based on the detail analysis new suggestions has been recommended.

Paper Type: A study on transformation of Indian Higher Education system: Present Scenario and Future Outlook.

Keywords: Indian Higher Education, Transformation, Knowledge based society, Challenges of Higher Education, Self-sustainable workforce.

\section{INTRODUCTION :}

The development of higher educational institutions in India is rapid in recent past due to globalization $\&$ swift development in science \& technology. There is an upsurge in the number of universities, institutions, especially autonomous [1]. National university of educational planning and administration has stated "the investment required in higher education is more than 9 lakh crore if we want to achieve $30 \%$ GER". The central and state governments simultaneously share the accountability for achieving comprehensive and sustainable growth of higher education.

There is a direct link between gross enrolment ratio (GER) in higher education and per capita GDP of any nation. HE has to be measured from various angles such as skill development, productivity, and optimum utilization of human resource [2]. HE obliges to accept different economic roles in the society and encourage innovation, which leads to economic development. There is a need to match supply and demand for various employability skills in the economy. For achieving the growth and development of industry, teaching-learning practice in higher education establishments such as colleges and universities should be developed. A system methodology for achieving policy consistency and multi-level synchronization on a long-term basis to tackle various deficiencies should be adopted.

\section{LITERATURE REVIEW :}

India has an edge globally in respect of availability of young skilled manpower but chronic deficiency such as poverty, illiteracy, imbalanced development, unemployment poses major hurdles to achieve her potential in industry acceptable skilled manpower. India is on the verge of becoming world's largest self-sustainability workforce, there is a need to collaborate technology with higher education policies and strategies to empower youth self-sustainability. 
Table 1: Review of Related area and its focus.

\begin{tabular}{|c|c|c|}
\hline $\begin{array}{c}\text { Serial } \\
\text { Number }\end{array}$ & Focus & Reference \\
\hline 1. & $\begin{array}{l}\text { There is a need to increase the number of institutes and also } \\
\text { the quality of higher education in India for sustaining the rate } \\
\text { of growth. }\end{array}$ & $\begin{array}{l}\text { Younis Ahmad sheikh, } \\
\text { (2017) [4]. }\end{array}$ \\
\hline 2. & $\begin{array}{l}\text { HE process will alter itself to a pupil-centric approach from } \\
\text { instructor-centric. There will be freedom to select from main } \\
\text { and similar subjects within and across the discipline. These } \\
\text { changes will conceive from the academic year 2021-22 till } \\
\text { the year } 2030 \text {. }\end{array}$ & $\begin{array}{l}\text { P. S. Aithal \& } \\
\text { Shubharajyotsna Aithal, } \\
\text { (2020) [1]. }\end{array}$ \\
\hline 3. & $\begin{array}{l}\text { This paper discusses societal expectation \& institutional } \\
\text { accountability through a core study of SIMS. The institution } \\
\text { monitors to maintain accountability through objective } \\
\text { criteria such as results, placements, impact of outreach } \\
\text { activities, students feedback \& employer feedback. }\end{array}$ & $\begin{array}{l}\text { Aithal P. S, P. M. Suresh } \\
\text { Kumar \& Deekshitha, } \\
(2015)[6] .\end{array}$ \\
\hline 4. & $\begin{array}{l}\text { In order to maintain high standards of higher education in } \\
\text { India, public policy should be on par with the development } \\
\text { of knowledge and technology. }\end{array}$ & $\begin{array}{l}\text { K. Kamar Jahan, and D. } \\
\text { Shristy Selvarani, (2015) } \\
\text { [17]. }\end{array}$ \\
\hline 5. & $\begin{array}{l}\text { The current quality of higher education should be upgraded } \\
\text { on parity with global standards. Expanding the concept of } \\
\text { making India a global hub for higher education is the } \\
\text { necessity of the hour and the process, system must be } \\
\text { simplified to fascinate more foreign students to Indian } \\
\text { establishments. The investment in higher education should } \\
\text { be encouraged to provide improved higher education in the } \\
\text { country. }\end{array}$ & $\begin{array}{l}\text { A R. Saravana kumar, K. } \\
\text { R. Padmini Devi, (2020) } \\
\text { [16]. }\end{array}$ \\
\hline 6. & $\begin{array}{l}\text { Emphasis should be given to five pillars education, } \\
\text { excellence, employment, export, and entrepreneurship in } \\
\text { collaboration with government, private, public, and } \\
\text { international support. }\end{array}$ & $\begin{array}{l}\text { Srimathi } \\
\text { Krishnamoorthy } \\
\text { (2019) [15]. }\end{array}$ \\
\hline 7. & $\begin{array}{l}\text { India being one of the prominent nations supplying highly } \\
\text { skilled manpower at low cost, hence by stressing on high- } \\
\text { quality research can overcome various hurdles faced by it. }\end{array}$ & $\begin{array}{l}\text { Devesh Nigam, M. P. } \\
\text { Ganesh, Suvashisa Rana, } \\
\text { (2020) [19]. }\end{array}$ \\
\hline
\end{tabular}

\section{OBJECTIVES :}

This paper is an endeavour to analyse the concept of transformation of higher education in India. The Objectives include:

(1) To understand the system and constitution of higher education in India.

(2) To review transformation of higher education based on All-India Survey of Higher Education (AISHE).

(3) To analyse National Educational Policy 2020 for a futuristic outlook in Indian Higher Education.

(4) To identify Strengths, Weaknesses, Opportunities, and Threats (SWOT) of higher education in India.

(5) To explore challenges encountered by higher education in India and recommend necessary suggestions.

\section{RESEARCH DESIGN :}

It is a qualitative conceptual study, based on secondary data. Secondary data is collected from websites, research papers, journals, articles, various surveys \& Government reports. This study includes a discussion with experts from the field of Higher education. 


\section{CONSTITUTION OF HIGHER EDUCATION IN INDIA :}

The structure of higher education in India consists of universities established under the parliament act, state legislature Act [3]. Deemed universities, institutions of national importance, colleges affiliated with universities are empowered to award degrees through parliament or state legislative Act.

The quality of higher education is assessed by key agencies such as National Assessment and Accreditation Council (NAAC) and National Board of Accreditation (NBA) for technical education set up by UGC in 1994 [4].

NEP 1986 stressed on upgrading the education sector by means of information technology. Prominence was given to the reorganization of teacher education, women's empowerment, initial childhood care, and adult literacy [5]. It recommended the quality of education services will be enhanced through the self-sufficiency of universities \& colleges. NEP 1986 was unsuccessful to increase the quality of higher education in generating graduates with employability skills $\&$ to produce research output. In order to overcome the loopholes, NEP 2020 has schemes of a liberal education to sustenance multidisciplinary education and research at the UG and PG levels [6]. Due to social, political pressures and also administrative lapses, there have been gaps between recommendations and implementation.

Under the department of Higher education, there are numerous regulatory bodies managing the activities of Higher Education in India. This is depicted in figure 1.



Fig. 1: Regulatory Bodies of Indian Higher Education

The Department of higher education, under the Ministry of Human Resource Development, has taken several initiatives to improve the overall development of the higher education sector, both in terms of planning and policy [7]. Some of the initiatives are as follows:

a. National Mission on Education through Information and Communication Technology (NMEICT)

b. Scheme for Promotion of Academic and Research Collaboration (SPARC)

c. Rashtriya Ucchatar Shiksha Abhiyan (RUSA)

d. Global Initiative for Academic Network (GIAN)

e. Education Quality Upgradation and Inclusion program (EQUIP)

f. Prime Minister's Research Fellowship (PMRF)

g. Higher Education Financing Agency (HEFA) 


\section{TRANSFORMATION OF HIGHER EDUCATION IN INDIA :}

The quantitative progression of universities and colleges in India is mentioned in Table 2. The tendency of growth is shown in Figure 2 and Figure 3. In India during 1990s and 2000 there is upward mobility in the growth of universities and colleges, the quantity of universities which was 184 has improved to 266, the number of colleges which was 5,748 has increased to 11,146. At present during 2018-19, the quantity of universities has increased more the 3 times from 266 to 993 and the number of colleges from 11,146 to 39,931 [8]. These trends indicate a positive transformation in the growth and development of Higher Education in India.

Table-2: The quantity of universities and colleges in India as per AISHE Report 2018-19

$\begin{array}{lll}\text { Year } & \text { Universities } & \text { Colleges } \\ 1950-51 & 28 & 578 \\ 1960-61 & 45 & 1,819 \\ 1970-71 & 93 & 3,227 \\ 1980-81 & 123 & 4,738 \\ 1990-91 & 184 & 5,748 \\ 2000-01 & 266 & 11,146 \\ 2018-19 & 993 & 39,931\end{array}$

Source: The quantity of universities and colleges in India as per AISHE Report 2018-19.

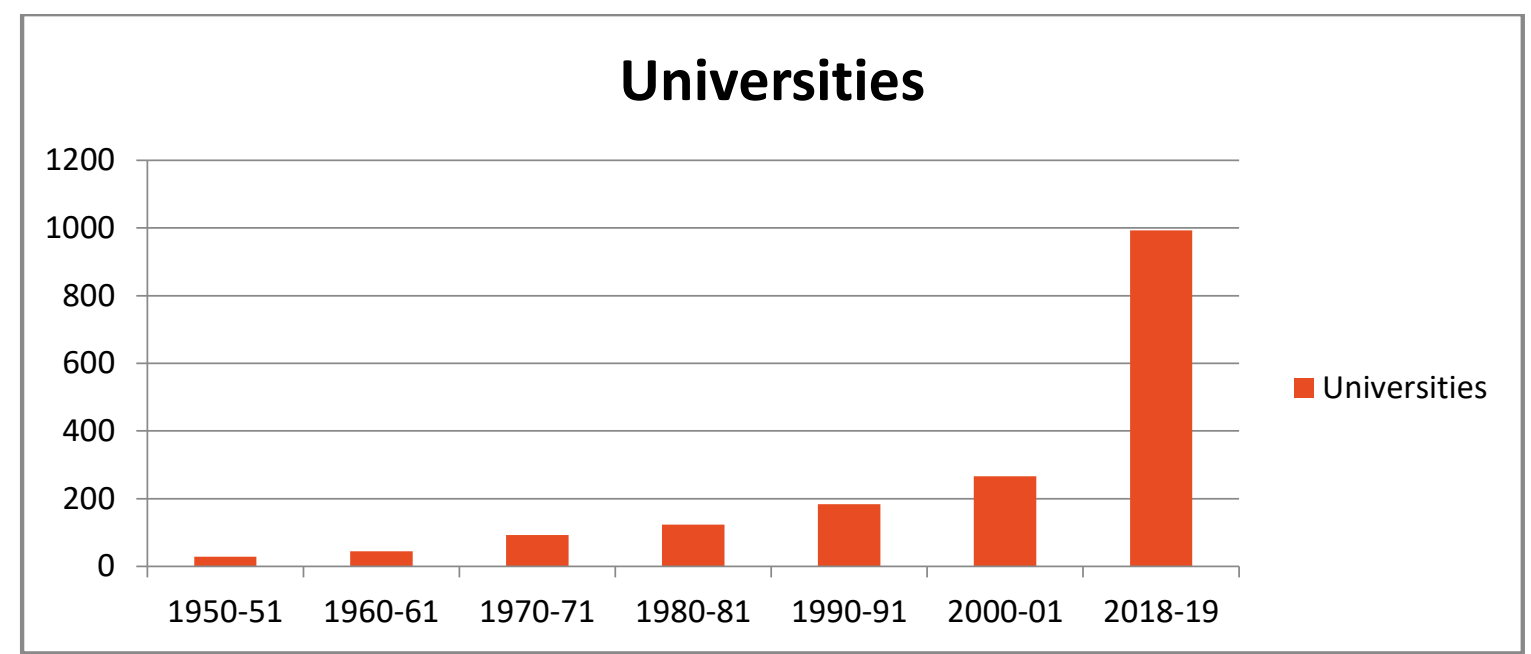

Fig. 2: The tendency of the growth of universities in India from 1950 to 2019

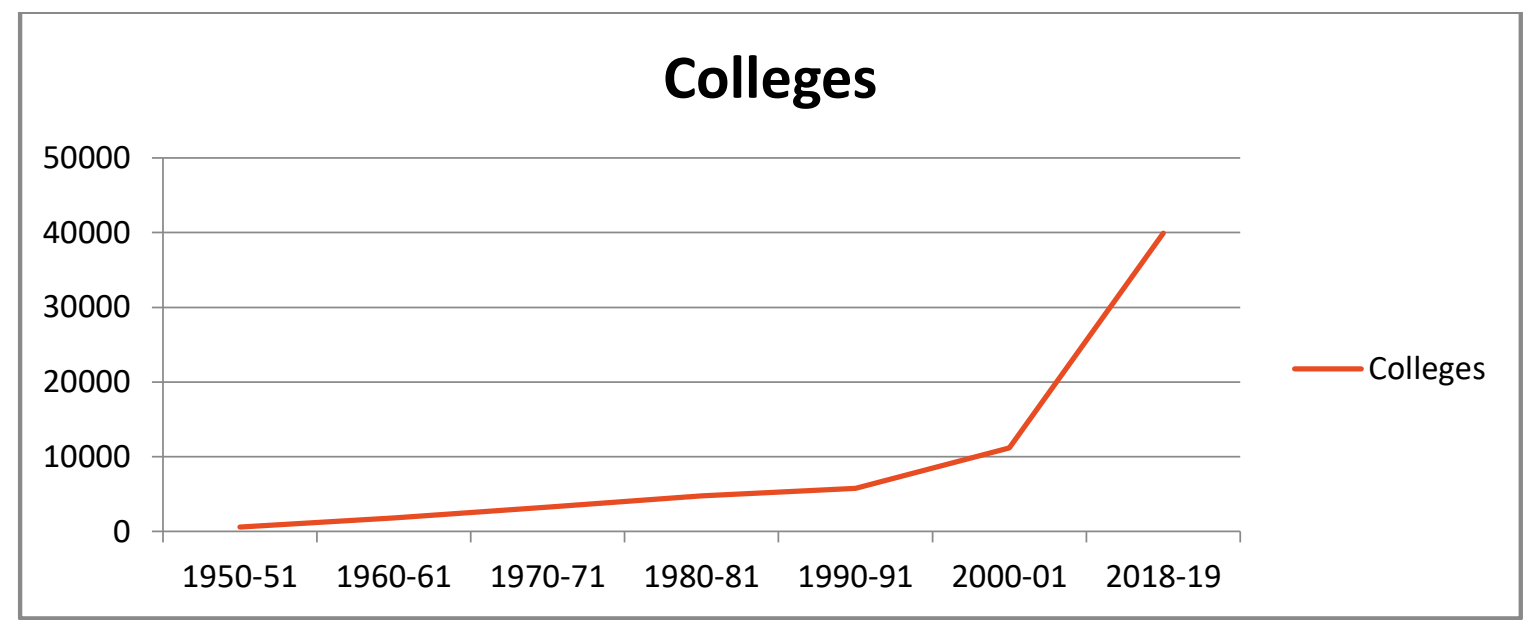

Fig. 3: The tendency of growth of colleges in India from 1950 to 2019.

As per the All-India Survey of higher education (AISHE) statement 2018-19, the gender gap in the country contracted as compared to the preceding year, i.e., 2017-18. The number of female students per 100 male students has gone up from 90 (2017-18) to 95 in 2018-19. The total enrolment in higher 
education has been projected at around 37.4 million, with a marginal rise in the gross enrolment ratio according to the findings [9].

\section{ANALYSIS OF NEP 2020 LEADING TO A FUTURISTIC OUTLOOK ON INDIAN EDUCATION :}

Due to the implication of NEP 2020, Indian Higher Education will undergo the following changes in the future:

(1) Transformation of narrow domain - Colleges have to opt for multidisciplinary autonomous degree-awarding institutions. This will enable the students to select the program of their choice.

(2) Elimination of Commercialization of Education - HE should always be service-oriented instead of profit, in case of both public and private There should be re-investment of any surplus profit for institutional development. This will reduce corruption and lobbies in colleges.

(3) Alteration of Public/Government Colleges - There are 2 options a) colleges become multidisciplinary and autonomous colleges. b) Several small and medium colleges change into an integral college of the affiliating university.

(4) Transformation of Private colleges - There are three alternatives (a) Small colleges with narrow domain and fewer students join and become Autonomous College. (b) These private colleges should upgrade their resources and quality of education to become Autonomous colleges after reaching predefined accreditation status. (c) Those private colleges failing to acquire pre-defined accreditation status should be closed [10].

(5) Merit-Based appointment - Appointments of Institutional Head should be based purely on Research \& Innovations. HEI Directors, Vice-Chancellors, etc. should have a minimum of first author publication for the last five years.

(6) Accountability on Decision Makers - Only Qualified Educationist with the scholarly publication, Patents, IPR should be given the chance to promote to the top position in higher education policy. At present Fake Educationist and bureaucrats who are relishing top positions may be cleaned from top decision-making roles.

(7) BOG made more responsible - Board of Governors should be made more accountable for maintaining the quality and consequences of HEI through transparent revelations of relevant records.

(8) Social Responsibility on Private HEIs - Societal Obligation such as Fees concession, scholarships, etc. is ingrained in the new model for private HEIs.

(9) Active role by Private Universities - Availability of 30\% free-ship and 40\% scholarships fees model in private universities to recover the reasonable cost for discharging social responsibilities, eligible students are self-motivated to join private universities.

(10) More stress on Research and Innovation - Availability of a lot of incentives permits students and faculty members to propose new things leading to novelty.

(11) Single HEIs Regulator - A single HEIs regulator should be set for efficient control of finance. All regulatory guidelines authorized by the NHERA, Board of governors have to meet, leading to more transparency in the implementation of the decisions and policies [11].

(12) Commitment to the HEIs - Those appointed in the highly educated BOG, who are dedicated and competent individuals, have proven proficiency can be loyal and committed to the institutions.

\section{SWOT ANALYSIS OF HIGHER EDUCATION IN INDIA :}

\section{Strength:}

(1) Active participation of government - In India, higher education is highly subsidized thus it is accessible to the poor. Due to application of principles of equity $\&$ accessibility by the central $\&$ state government, has facilitated many of the economically poor to get education. The government is increasing efforts to assist universities in the development of higher education.

(2) Internationally recognized educational programs and specialized courses - English as a medium of instruction, has benefitted India for achieving globally accepted higher education. Several Indian universities of distinction have acquired deemed and autonomy Universities status. Such universities are establishing offshore campuses abroad such as IIMs, IITs, IISC, TATA and are recognized internationally [12]. 
(3) Good image of Indian medical and engineering education globally - Increase in the number of partnerships and MOU among various medical and technical education with developed countries has increased strategic alliances in recent years.

(4) Rise in the flow of Publications and research activities - Compulsion by UGC for completion of $\mathrm{Ph}$.D. to be eligible for teaching in higher education institutions has improved the flow of publications and research activities.

(5) Quality HE for social change - Higher education has proved as a device of social change by enhancing the quality. The establishment of NAAC by UGC and NBA by AICTE, a significant creativity towards achieving quality is undertaken.

\section{Weakness:}

(1) Inappropriate funding - Existing universities are facing a severe fund crunch. Most of the universities suffer from a lack of infrastructure, equipment, and facilities for student welfare, career guidance, counselling, and advanced research.

(2) Lack of faculty development - For optimum utilization of human resource, development and training of faculty is necessary. Due to misallocation of funds and corruption the teachers lack up-todate knowledge and experience.

(3) Overlapping function - The department of higher education has many apex agencies like NAAC, UGC, AICTE, NBA, etc. to improve the development of the higher education sector. The functions of these multiple agencies overlap.

(4) Lack of equality of educational opportunities - GER among different sects of the society lacks equity. The GER in higher education among males and females varies to a greater extent $\mathrm{n}$ India according to previous studies [13].

(5) Autonomy of universities - There is no corresponding increase in accountability in Autonomous and Deemed universities.

(6) Lack of link with developmental processes - There is no connection between higher education with developmental processes, leading to frustration amongst students when they are not able to find employment.

(7) High cost of HE - Professional course is made lucrative by many private institutions by adopting various marketing strategies, majority of Indian middle and lower classes cannot afford the high fees.

\section{Opportunities:}

(1) Young and Diverse country - India has 150 million youth population, but the educational infrastructure is inadequate to manage such huge volumes. Therefore, investment should be encouraged from private and foreign in higher education.

(2) Digital Learning and Learning Tools - With the assistance of digital learning tools, countries like India could overcome the various challenges faced for achieving proficiency in higher education [14].

(3) Equality of Educational opportunity - In order to reduce income \& wealth inequalities, higher education could be used as a powerful tool by providing equal educational opportunity in higher education in India.

(4) Collaboration of EI and Industries - To enhance the employability skills of graduates, there is a need to link Higher Education with industry, research skills, vocational training, entrepreneurship, etc.

(5) Linking of National and International HE - Future prospects for strategic collaboration in higher education between the National \& International platforms can be encouraged through participation in conferences, seminars, workshops, etc. [15].

(6) Investment Opportunities - Due to increase in the youth population in the country and lack of funds, there is immense scope for investment in both regulated \& non-regulated sectors

\section{Threat:}

(1) Inadequate infrastructure - To be on par with international standards development of infrastructure is paralyzed due to lack of funds. Central, as well as State government, does not have enough funds for existing universities and educational institutions how they could commission new varsity.

(2) Resistance by stakeholders - HE lacks flexibility in controlling the development of higher education due to mismanagement and authoritative decision-making by various agencies of HE. [16]. 
(3) Political intervention - Interference in governing body of the universities by political leaders, as most of the educational establishments are owned by them. Innocent students are brainwashed for their selfish means.

(4) Loopholes in Research - Maximum numbers of the research do not add to knowledge but only create additional data [17]. This obstructs the utilization of research funds, quality in higher education, and curriculum development.

(5) Inappropriate distribution of National and International Funds - Fiscal uncertainties, corruption, mismanagement through misuse of powers adversely affect the appropriate distribution of funds.

(6) Fear of Terrorism - Frequent terrorist attack has discarded the development of higher education. National security is at stake due to terrorism.

(7) Commercialization of $\mathrm{HE}$ - Professional education is commercialized in spite of government intervention. Traditional courses are pursued by the majority of students without any alternative to other courses.

(8) Narrow Domains - Multidisciplinary domain is absent in most of the universities and educational institutions. There is the absence of Job oriented courses providing employment.

(9) Lack of Academic audit - To sustain the jobs of several teachers and the survival of certain departments, several courses are introduced. The lack of an academic audit mechanism makes it impossible for providing financial assistance on the basis of academic audits.

\section{CHALLENGES OF HIGHER EDUCATION IN INDIA :}

(1) Low Student Enrolment rate - Due to the lack of access to higher education in socio-economically disadvantaged places, the gross enrolment ratio (GER) is $25 \%$. There is a huge demand-supply gap.

(2) Inadequate facilities and infrastructure - Most of the institutions are established in rural areas with poor facilities and infrastructure with just a few teachers. There is a lack of financing support from the government and society to higher education.

(3) Large vacancies in faculty positions - There is a lack of quality education in higher education. The number of teachers is limited and due to lack of training do not possess adequate knowledge [18].

(4) Outmoded teaching methods - The curriculum is not upgraded on par with the development of science and technology, challenges from the international universities, and globalization. Career management and progression of teachers are adversely affected due to insufficient mechanisms.

(5) Lack of research work - Research work is almost low in higher educational institutions due to a lack of financial support from the government and society. Global recognition is adversely affected by lack of research work.

(6) Lack of optimum governance and Leadership - For the optimum administration of HE, the total networking of the system consisting of concepts of relevance, equity, access, and quality should be effectively governed under able leadership.

(7) Teaching shop - Currently almost all universities are suffering from lack of adequate infrastructure, faculty, and finances. Many of them have shrunk as mere 'teaching shops' as they are run by guest faculty.

(8) Lack of Fund - One of the major concerns raised by the varsity administrators is that the state government does not have enough funds to give the existing ones, why should it think of starting new universities?

(9) Narrow Domains - Many of the new universities are in a narrow discipline of knowledge such as hospitality, tourism, etc. These can be added just as a new branch or a PG centre instead of a new university.

(10) Faculty - In spite of large numbers of NET/Ph.D. candidates, the department of higher education has failed to attract and retain qualified teachers. There is a lot of vacancies which is not filled adequately, compelling deserving candidates to apply in other departments [19].

(11) Accreditation - According to the statistics provided by the NAAC, June 2010, "not even $25 \%$ of the total higher education institutions in the country were accredited. Among those accredited, only $30 \%$ of the universities and $45 \%$ of the colleges were found to be of quality to be ranked at 'A' level". (12) Quota system - The quality of HE has vanished because of the reservation and quota system. Eligible candidates of general categories are overlooked and unsuitable candidates from reserved categories are selected. 
(13) Fake colleges - Excellent innovative institutions are ignored allowing fake colleges to grow by the corrupted regulatory systems and fraudulent bureaucratic structures. Lack of accountability, professionalism, transparency poses challenges to the management of the Indian education system [20].

\section{SUGGESTIONS :}

(1) Good infrastructure of colleges and universities - Colleges and Universities should be adequately equipped with good infrastructure and facilities, which may attract the students and will raise the GER ratio.

(2) Self-sufficiency to the Private Sector - For accomplishing the United Nations Sustainable goal of imparting quality education to all, the private and public sectors in education should involve as parallel by granting autonomy to the private sector.

(3) Boosting of self-financing universities - All public universities are underfunded, have faculty shortages, infrastructure deficiencies, and no research. Self-sustenance of the public universities should be encouraged.

(4) Plan for improving Quantity of Universities - To increase GRE there is a need for constituting more universities by the accreditation of several self-finance colleges and adopting once in three years academic and administrative audit by external experts.

(5) Improving Quality - Quality in education can be enhanced by adding aspects of human values, ethics, social justice \& environmental safeguards to the curriculum. For better quality, collaboration between top international institutes and Indian institutes of HE should be promoted by the Government along with links between research centres of top institutions \& National research centres.

(6) Collaboration between HE and Industries - Job-oriented courses should be inbuilt programme for graduates so that they can achieve deep knowledge and excellence in the subject so that they could be recruited by the companies after graduation, which would decrease unnecessary rush to higher education.

(7) Linking HE with development - The present model of higher education should be linked to developmental education, collaborating education to developments in industry, society, and services sectors.

(8) No political Interference - The education system should be liberated from political affiliations, favouritism, and corruption in both public and private universities and colleges.

(9) Encouragement to Multidisciplinary Courses - Courses must have a multidisciplinary approach, should have at least five disciplines of different areas such as Law, Commerce, Agriculture, Business Management, social science, computer science, medical science, engineering, etc. Narrow domains should be avoided.

(10) Elimination of Obsolescence in Higher Education System - Colleges, universities that do not perform and obsolete human resources working in such institutions should be eliminated from time to time based on strict accountability and policies measure.

(11) Publication Unit in the campus - Universities should have their own digital publication units to publish excellent research and articles in their journal, which could be shared in global indexing units.

(12) Career-based Training - Training based on earn while learn should be promoted so that students develop skills that are more productive and economic, thereby reducing dependency on their parents.

(13) HEIs should be made accountable - There is a need for developing educational management system whereby Universities and colleges must be evaluated in terms of their performance, process and outcomes. For the use of public funds, accountability should be strictly implemented.

(14) An opportunity for gig economy - India should encash gig economy for job creation and economic growth. The present educational policymakers should tap this opportunity in their decision and policy framing relating to higher education.

(15) Digital Libraries - All higher education institutions should register with INDL Integrated National Digital Library, and acquire membership for converting into a Digital library.

\section{CONCLUSION :}

Education is a system by which an individual's body, mind, and personality are shaped and strengthened. It is the organization of head, heart, mind and thus allowing a person to develop an optimum personality recognizing the best in him or her. In the last decades, Indian higher education has leaped forward but it is not equally accessible to all. 
Opportunities are available but how to reap the benefits and make them accessible to all is a matter of concern. In order to achieve sustainable development in India, there is a need to increase the quantity and quality of higher education institutes. In order to increase GER, the strengthening of the existing universities should not come at the cost of new universities. There is a vital need to relook at the quality criteria, access, infrastructure, financial resources, relevance, equity, and finally the readiness of higher education for accomplishing India's future requirements. India is burdened by various challenges and threats in higher education but foremost importance should be given to tackle these challenges and boost higher education for its future growth and raising its per capita GDP [21].

\section{REFERENCES :}

[1] Aithal, P. S., Suresh Kumar P. M. and Deekshitha, (2015). Societal Expectation and Institutional Accountability in Higher Education. International Journal of Management, IT and Engineering (IJMIE), 5(7), 362-373.

[2] National Education Policy 2020. http://www.mhrd.gov.in/sites/upload files/mhrd/files/nep/NEP Final English.pdf.

[3] Deepthi Gupta, Navneet Gupta (2012). Higher Education in India: Structure, statistics and challenges. Journal of Education and Practice, 3(2), 17-21.

[4] Younis Ahmad sheikh (2017). Higher Education in India: challenges and Opportunities. Journal of Education and practice, 8(1), 39-42.

[5] About NAAC. National Assessment and Accreditation council. Retrieved from http://naac.gov.in/index.php/about-us\#vision.

[6] Aithal, P. S. \& Shubhrajyotsna Aithal (2020). Analysis of the Indian National Education Policy 2020 towards Achieving its Objectives. International Journal of Management, Technology, and Social Sciences (IJMTS), 5(2), 19-29.

[7] About MHRD. Retrieved from http://mhrd.gov.in/about-mhrd.

[8] AISHE Report 2018-19. Retrieved from http://aishe.nic.in/aishe/reports.

[9] UGC report: "Higher Education in India: Issues related to expansion, inclusiveness, quality and finance" 2008. https://ugc.ac.in/oldpdf/pub/report/12.pdf.

[10] Aithal, P. S. \& Aithal, Shubhrajyotsna (2019). Analysis of Higher Education in Indian National Education Policy Proposal 2019 and its Implementation Challenges. International Journal of Applied Engineering and Management Letters (IJAEML), 3(2), 1-30.

[11] Aithal, P. S. (2016). Creating Innovators through setting up organizational Vision, Mission and Core Values: a strategic Model in Higher Education. International Journal of Management, IT and Engineering (IJMIE), 6(1), 310-321.

[12] British Council, Understanding India - The Future of Higher Education and opportunities for International Cooperation, 2014.

[13] Aithal, P.S. \& Aithal, Shubhrajyotsna. 2020. Conceptual Analysis on Higher Education Strategies for Various Tech-Generations. International Journal of Management, Technology, and Social Sciences (IJMTS), 5(1), 11-22.

[14] Sharma \& Sharma. (2015). Indian Higher Education System: Challenges and Suggestions. Electronic Journal of Inclusive Education, 3(4), 1-5.

[15] Srimathi H. Krishnamoorthy A. 2019. Higher Education system In India: challenges And Opportunities. International Journal of Scientific \& Technology Research, 8(12), 213-217.

[16] Saravana kumar, A. R. Padmini Devi, K. R. (2020). Indian Higher Education: Issues and Opportunities. Journal of Critical Reviews, 7(2), 542-545.

[17] Kamar Jahan K, and Shristy Selvarani, D. (2015). Higher Education in India: Issues and challenges. Journal of Education and Practice, 3(6), 81-86. 
[18] Aithal, P. S. \& Suresh Kumar, P. M. (2016). Student Evaluation and Reforms in Higher Education Institutions. International Journal of Multidisciplinary Research and Modern Education (IJMRME), 2(1), 625-661.

[19] Devesh Nigam, Ganesh, M. P., Suvashisa Rana. (2020). Review of the expansion of Higher education in India: Cardinal concerns in the traverse. Journal of Critical Reviews, 7(2), 97-102.

[20] Desh Raj Sirswal. (2016). Higher Education and Research in India: An overview. Intellectual Quest, 5(2), 26-38.

[21] Aithal, P. S., \& Aithal, S. (2020). Implementation Strategies of Higher Education Part of National Education Policy 2020 of India towards Achieving its Objectives. International Journal of Management, Technology, and Social Sciences (IJMTS), 5(2), 283-325.

$* * * * * * * * * * * * * *$ 